Research review paper

\title{
Recombinant microbial systems for improved $\beta$-galactosidase production and biotechnological applications
}

\author{
Carla Oliveira, Pedro M.R. Guimarães, Lucília Domingues* \\ IBB - Institute for Biotechnology and Bioengineering, Centre of Biological Engineering, Universidade do Minho, Campus de Gualtar, 4710-057 Braga, Portugal
}

\section{A R T I C L E I N F O}

\section{Article history:}

Received 10 September 2010

Received in revised form 24 January 2011

Accepted 31 March 2011

Available online 13 April 2011

\section{Keywords:}

Recombinant $\beta$-galactosidase

Thermophilic enzymes

Cold-adapted enzymes

Recombinant microbial systems

Transgalactosylation activity

Milk lactose hydrolysis

Whey bioremediation

\begin{abstract}
A B S T R A C T
$\beta$-Galactosidases (EC 3.2.1.23) constitute a large family of proteins that are known to catalyze both hydrolytic and transgalactosylation reactions. The hydrolytic activity has been applied in the food industry for decades for reducing the lactose content in milk, while the transgalactosylation activity has been used to synthesize galacto-oligosaccharides and galactose containing chemicals in recent years. The main focus of this review is on the expression and production of Aspergillus niger, Kluyveromyces lactis and bacterial $\beta$-galactosidases in different microbial hosts. Furthermore, emphasis is given on the reported applications of the recombinant enzymes. Current developments on novel $\beta$-galactosidases, derived from newly identified microbial sources or by protein engineering means, together with the use of efficient recombinant microbial production systems are converting this enzyme into a relevant synthetic tool. Thermostable $\beta$-galactosidases (cold-adapted or thermophilic) in addition to the growing market for functional foods will likely redouble its industrial interest.
\end{abstract} (c) 2011 Elsevier Inc. All rights reserved.

\section{Contents}

1. Introduction .........6 600

1.1. The $\beta$-galactosidase enzyme . . . . . . . . . . . . . . . . . . . . . . . . . . . . . . 600



2. Recombinant microbial systems for $\beta$-galactosidase production . . . . . . . . . . . . . . . . . . . . . . . . . . . 602

2.1. Recombinant expression of non-bacterial $\beta$-galactosidases . . . . . . . . . . . . . . . . . . . . . . . . . . 602

2.1.1. Heterologous production of $A$. niger $\beta$-galactosidase $\ldots \ldots \ldots \ldots$

2.1.2. Heterologous production of $K$ lactis $\beta$-galactosidase ～. . . . . . . . . . . . . . . . . . . . . . 603

2.2. Recombinant expression of bacterial $\beta$-galactosidases . . . . . . . . . . . . . . . . . . . . . . . . . 6 604

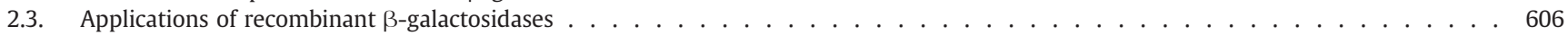

2.3.1. Milk lactose hydrolysis . . . . . . . . . . . . . . . . . . . . . . . . . . . 606

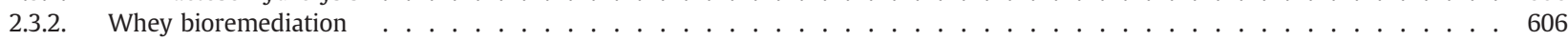

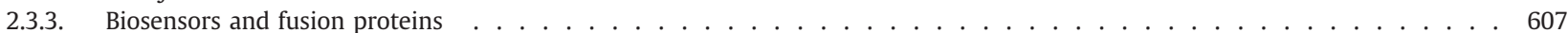

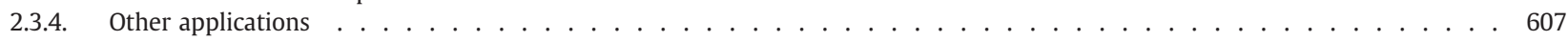

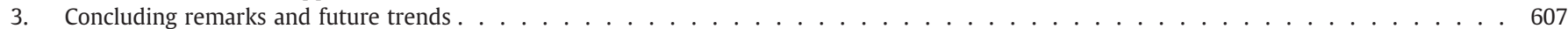

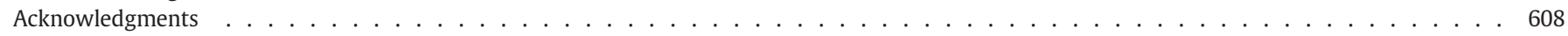

References $\ldots . \ldots . \ldots$

\section{Introduction}

\subsection{The $\beta$-galactosidase enzyme}

$\beta$-galactosidase (commonly also known as lactase) is an enzyme (EC 3.2.1.23) that catalyzes the hydrolysis of terminal non-reducing

\footnotetext{
* Corresponding author. Tel.: + 351253604 400; fax: + 351253678986. E-mail address: luciliad@deb.uminho.pt (L. Domingues).
}

$\beta$-D-galactose residues in $\beta$-D-galactosides (http://expasy.org/enzyme/ 3.2.1.23; Gasteiger et al., 2003). Conventionally, its main application has been in the hydrolysis of lactose in milk or derived products, particularly cheese whey. More recently, $\beta$-galactosidases with transgalactosylation activities (i.e. which can oligomerise galactosides) have been extensively exploited for the production of functional galactosylated products (Fig. 1).

Many organisms naturally synthesize $\beta$-galactosidase, including microorganisms, plant and animal cells (Husain, 2010; Panesar et al. 2006). Traditionally, the $\beta$-galactosidases most widely used in industry 
$\beta$-galactosidase
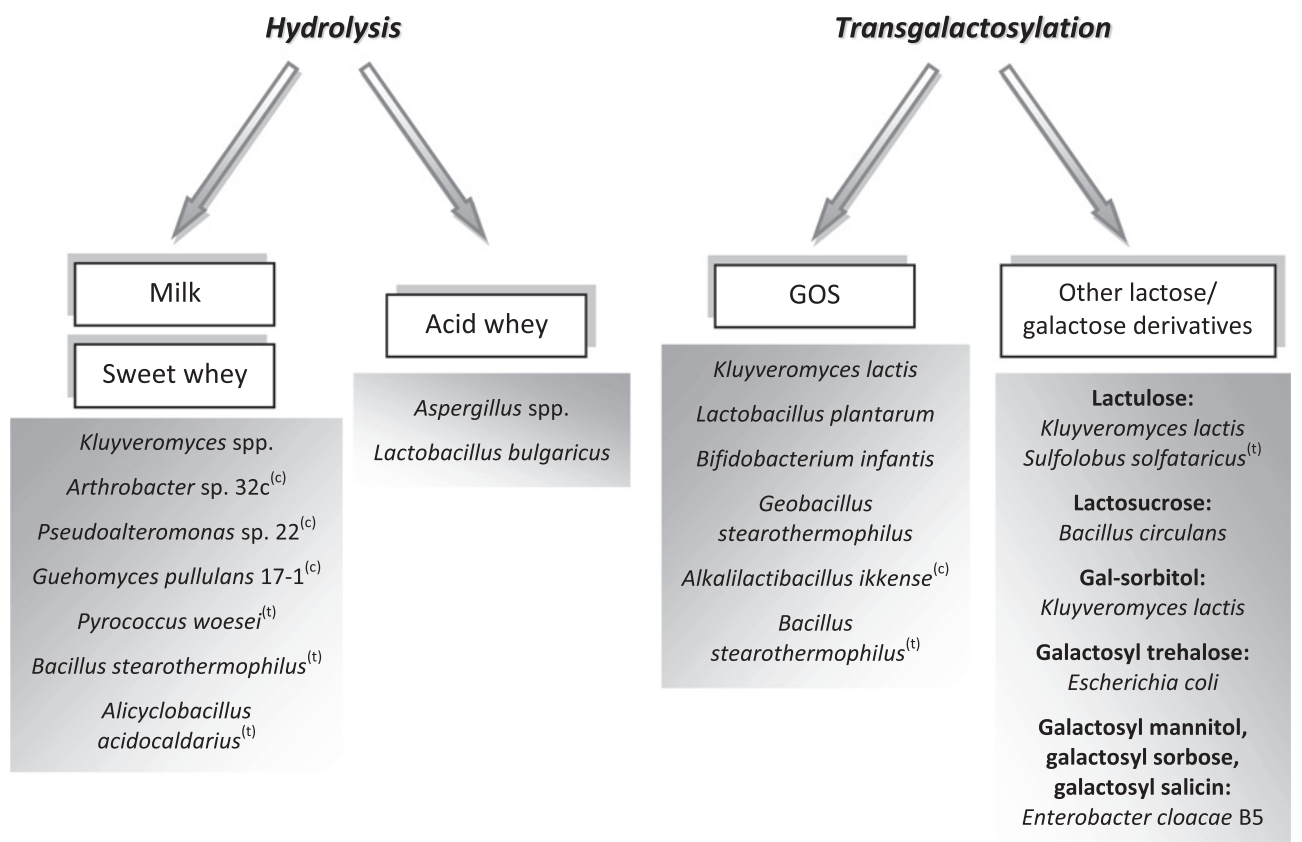


transgalactosylation reactions. The gray boxes show examples of microbial enzyme sources for each application. ${ }^{(\mathrm{c})}$ Cold-active enzymes; ${ }^{(\mathrm{t})}$ thermophilic enzymes.

were obtained from Aspergillus spp. and Kluyveromyces spp. (Husain, 2010; Panesar et al., 2006; Siso, 1996; Zadow, 1984), because these could be readily obtained with acceptable productivities and yields from cultivations of these microorganisms. Additionally, products obtained from these organisms are generally recognized as safe (GRAS status) for human consumption, which is critical for food related applications (Kosseva et al., 2009; Panesar et al., 2006; Siso, 1996). In Aspergillus spp. $\beta$-galactosidase is secreted to the extracellular medium. These fungal enzymes have a pH optimum in the acidic range (2.5-5.4) and a high temperature optimum that allows their use at temperatures up to $50^{\circ} \mathrm{C}$ (Panesar et al., 2006; Zadow, 1984). Their main application is in the hydrolysis of acid whey, which derives from the production of fresh or soft cheeses (Yang and Silva, 1995). Conversely, in Kluyveromyces spp. the $\beta$-galactosidase is intracellular; lactose is first transported to the interior of the yeast cell by a permease and then hydrolyzed intracellularly to glucose and galactose, which follow the glycolytic pathway or the Leloir pathway, respectively (Domingues et al., 2010). The yeast enzyme has a near neutral optimum $\mathrm{pH}$ (6.0-7.0) and therefore has a broader range of applications, particularly in the hydrolysis of milk and sweet whey (derived from hard cheese manufacturing) (Panesar et al., 2006; Yang and Silva, 1995; Zadow, 1984). Because of its intracellular nature, the enzyme needs to be extracted from the yeast cells by disrupting or permeabilizing the cells using chemical and/or mechanical treatments (Panesar et al., 2006).

Panesar et al. (2006) compiled a list of $\beta$-galactosidase commercial preparations. Yeast sources are Kluyveromyces lactis and Kluyveromyces marxianus (species that now includes former species Kluyveromyces fragilis and Saccharomyces fragilis as well as its anamorph Candida pseudotropicalis; Lachance, 1998), while fungal sources include Aspergillus niger and Aspergillus oryzae. The $\beta$-galactosidase from Escherichia coli is the most extensively studied but its industrial use is hampered by the fact that it is not considered safe for food applications. Nevertheless, it is commercially available for analytical purposes (Panesar et al., 2006; Siso, 1996). Finally, a preparation obtained from Bacillus sp. is also commercialized (Panesar et al., 2006).
Lactic acid bacteria (include a diverse group of lactococci, streptococci and lactobacilli) and bifidobacterium, which are recognized as safe organisms, have been regarded as good sources of $\beta$-galactosidases, especially for functional food applications (Husain, 2010). More recently, there has been growing interest in a considerable number of $\beta$-galactosidases from other sources that present diverse properties of biotechnological interest (Panesar et al., 2006). Particular attention has been rewarded to thermotolerant or cold-active enzymes from yeast and bacterial sources (Husain, 2010; Panesar et al., 2006; Park and Oh, 2010b). The X-ray crystal structures of several microbial $\beta$-galactosidases have been unraveled, although none of the enzymes with solved structures is known to be used in food processing (Gosling et al., 2010).

Nowadays, recombinant DNA technology can be used to express and optimize the production of interesting $\beta$-galactosidases from the most diverse sources in microbial hosts that are recognized for their highly efficient heterologous protein production. This possibility greatly expands the range of potential applications for $\beta$-galactosidases and their economically effective utilization in industrial processes. Modern molecular biology tools combined with bioprocess engineering strategies can be used to optimize protein production, resulting in technically and economically effective enzyme production systems. Besides the wide-ranging properties offered by natural sources, new features - such as reduced product inhibition (Park and Oh, 2010b), higher product yields (Gosling et al., 2010) or secretion signals (Becerra et al., 2001b) may be built into specific $\beta$-galactosidases using state-of-the-art protein engineering tools.

\subsection{Applications of $\beta$-galactosidase}

Lactose is a disaccharide formed by glucose and galactose that is found in milk. In humans, lactose intolerance or lactose malabsorption is a common problem. In fact, it is estimated that over $70 \%$ of the world's adult population have problems in digesting lactose (Adam et al., 2004; Husain, 2010; Lifran et al., 2000), resulting from absent or reduced 
$\beta$-galactosidase activity in the small intestine. Indigested lactose therefore passes into the large intestine where it is fermented by colonic microflora causing symptoms such as abdominal pain, gas, nausea and diarrhea (Adam et al., 2004; Husain, 2010). The extent of these symptoms is variable and indeed most individuals can tolerate a moderate amount of lactose in their diet (Lifran et al., 2000). Nevertheless, there is a considerable market for lactose-free milk and dairy products, which can be obtained by enzymatic hydrolysis using $\beta$ galactosidases.

The solubility and sweetness of lactose is low compared to other sugars, including glucose, galactose, fructose and sucrose (Gänzle et al., 2008; Zadow, 1984). Therefore, lactose hydrolysis diminishes precipitation problems and enhances the sweetening power, thus expanding the food applications of lactose solutions, for instance in the confectionary and ice-cream industries replacing sucrose or starch syrups (Siso, 1996; Zadow, 1984).

Besides milk, the main source of lactose is cheese whey, which is a primary by-product of cheese manufacturing. About $9 \mathrm{~L}$ of whey stream are generated during the production of $1 \mathrm{~kg}$ of cheese, amounting to over 160 million $t$ of whey produced worldwide each year (Guimarães et al., 2010). Whey's organic load is high (biochemical oxygen demand of $30-50 \mathrm{~g} / \mathrm{L}$ and chemical oxygen demand of $60-80 \mathrm{~g} / \mathrm{L}$ ), mainly because of the lactose content, which together with the high volumes to which it is generated makes cheese whey a quite concerning environmental issue, and solutions for its valorization are strongly required (Guimarães et al., 2010). In this regard, lactose hydrolysis by $\beta$-galactosidases again plays an important part by broadening whey's applications. Particularly, whey fermentations can be expanded beyond the somewhat limited capacities of lactose-consuming microorganisms, to the use of lactose-hydrolyzed whey as feedstock for the production of added-value molecules or bulk commodities by lactose-negative microbes. For instance, Saccharomyces cerevisiae wild strains (lactosenegative) can be used to produce ethanol from hydrolyzed whey, although catabolite repression-resistant mutants must be applied in order to avoid glucose-galactose diauxy (Bailey et al., 1982; Terrell et al., 1984). In the case of low-price bulk products, like ethanol, the cost of $\beta$-galactosidase for hydrolysis is often the bottleneck limiting the economical viability of the fermentation process.

Apart from lactose hydrolysis, $\beta$-galactosidases with transgalactosylation activities are highly attractive for the production of added-value lactose derivatives (Fig. 1). In particular, galacto-oligosaccharides (GOS) are increasingly finding application in functional foods, namely as lowcalorie sweeteners in fermented milk products, confectioneries, breads and beverages. The use of $\beta$-galactosidades for the production of GOS has been most recently reviewed (Gosling et al., 2010; Park and Oh, 2010b).

There are two main options for the industrial application of $\beta$-galactosidases: the "free enzyme" route using $\beta$-galactosidase in solution or the use of immobilized enzyme bioreactors (Gänzle et al., 2008). The free enzyme approach is technically simpler but the soluble enzyme can hardly be reused, which represents a main drawback taking into account the high costs of enzyme preparations. Nevertheless, membrane technology, mostly based in ultrafiltration membranes that are not permeated by $\beta$-galactosidase, has been explored for recovering and reusing the soluble enzyme (Gosling et al., 2010; Richmond et al., 1981). Immobilization technology although technically more challenging provides enzyme recycling and the possibility of continuous operation and may in some cases result in enhanced enzyme stability. The methods for $\beta$-galactosidase immobilization as well as their applications and the diverse bioreactor systems proposed for its use have been recently reviewed (Husain, 2010; Kosseva et al., 2009; Panesar et al., 2006). The utilization of whole cells provides an alternative to circumvent the technical and economical efforts associated with enzyme extraction and isolation/purification. The major drawback is the poor permeability of cell membranes to lactose, although the permeability of microbial cells can be increased by treatment with chemical agents, such as detergents or solvents (Panesar et al., 2006).

\section{Recombinant microbial systems for $\beta$-galactosidase production}

\subsection{Recombinant expression of non-bacterial $\beta$-galactosidases}

This section focuses on the heterologous expression and production of the $\beta$-galactosidases most used in the food industry, that is from the filamentous fungi $A$. niger and from the yeast $K$. lactis in recombinant yeast hosts (summarized in Table 1 ).

The definition of the $\beta$-galactosidase enzymatic activity unit (U) is not equivalent in the reports concerning $\beta$-galactosidase from $K$. lactis and from $A$. niger. Hereafter, $1 \mathrm{U}$ is defined as the amount of enzyme that hydrolyses $1 \mathrm{nmol}$ of p-nitrophenyl- $\beta$-D-galactopyranoside (pNPG) or o-nitrophenyl- $\beta$-D-galactopyranoside (oNPG) per min, and for consistency the reported values for $K$. lactis $\beta$-galactosidase were converted to this enzymatic unit.

\subsubsection{Heterologous production of $A$. niger $\beta$-galactosidase}

The filamentous fungi $A$. niger has the ability to secrete $\beta$-galactosidase into the extracellular medium, which obviously facilitates the recovery of the enzyme. This $\beta$-galactosidase is only suitable for the hydrolysis of acid whey because its activity at $\mathrm{pH}$ values higher than optimum (around 3.5) is quite diminished. Aiming this application, and to improve its availability, $A$. niger $\beta$-galactosidase was cloned and produced in recombinant $S$. cerevisiae strains.

A yeast multicopy expression vector carrying the cDNA for $A$. niger secretory $\beta$-galactosidase under the control of $A D H 1$ promoter and terminator (lacA cassette) was constructed (plasmid pVK1.1) (Kumar et al., 1992). This vector was used to engineer different recombinant $S$. cerevisiae strains with the capacity to produce and secrete $A$. niger $\beta$-galactosidase (Domingues et al., 2000a; Domingues et al., 2002; Kumar et al., 1992; Oliveira et al., 2007; Ramakrishnan and Hartley, 1993). However, in the initial works, recombinants demonstrated low growth rates on lactose (Kumar et al., 1992) or, despite rapid growth and good fermentation characteristics under aerobic conditions, showed low plasmid stability (10\%) (Ramakrishnan and Hartley, 1993). Although recombinant $\beta$-galactosidase has been detected in the culture medium as desired, its activity level was unsatisfactory (Ramakrishnan and Hartley, 1993; Table 1). In our research group, flocculating recombinant yeasts secreting high levels of $A$. niger $\beta$ galactosidase have been obtained (Domingues et al., 2000a; Domingues et al., 2002; Oliveira et al., 2007). The advantage of using flocculating yeast cells is that it allows for continuous recombinant protein production in high-cell-density systems. Due to their sedimentation characteristics, increasing biomass concentration is attained inside the bioreactor, leading to high recombinant protein productivities and minimizing the risk of contamination (Domingues et al., 2000b). In addition, the recovery of cells from media is facilitated, reducing the downstream processing costs (Domingues et al., 1999). The capacity of flocculating yeast cells to secrete recombinant $\beta$-galactosidase was for the first time demonstrated using a brewer's yeast strain, transformed with a recombinant vector containing the lacA cassette from pVK1.1 and a copper resistance selection marker (CUP1 gene) (Domingues et al., 2000a; Table 1). However, the flocculating yeast strain S. cerevisiae NCYC869-A3, transformed with the pVK1.1 vector, was able to produce 20 times more $\beta$-galactosidase activity in identical medium containing less lactose (Domingues et al., 2002; Table 1). Therefore, optimization of the large-scale production of $A$. niger recombinant $\beta$-galactosidase was conducted with this recombinant yeast strain. The production of recombinant $\beta$-galactosidase in a 2-L bioreactor with controlled agitation, aeration, $\mathrm{pH}$ and temperature was carried out varying the lactose and yeast extract concentrations in semi-synthetic medium (SSlactose) (Domingues et al., 2002; Domingues et al., 2004). The recombinant $\beta$-galactosidase activity increased linearly with increasing 
Table 1

Heterologous production of Aspergillus niger and Kluyveromyces lactis $\beta$-galactosidases in yeast hosts.

\begin{tabular}{|c|c|c|c|c|}
\hline $\begin{array}{l}\text { Source of } \\
\text { the enzyme }\end{array}$ & Expression host/plasmid & Media and culture conditions & Extracellular recombinant $\beta$-galactosidase activity & References \\
\hline \multirow[t]{9}{*}{ A. niger } & Mauri distiller's yeast/pVK1.1 & $\begin{array}{l}\text { Modified } \mathrm{D}_{\mathrm{w}} \text { medium }+10 \% \text { lactose } \\
(2 \text { - } \mathrm{L} \text { bioreactor })\end{array}$ & $10 \mathrm{U} / \mathrm{mL}$ & $\begin{array}{l}\text { Ramakrishnan and } \\
\text { Hartley, } 1993\end{array}$ \\
\hline & $\begin{array}{l}\text { Brewer's yeast W204-FLO1L/ } \\
\text { pET13.1 + lacA cassette (pLD1) }\end{array}$ & SSlactose $2 \%$ (shake flasks) & $17 \mathrm{U} / \mathrm{mL}$ & $\begin{array}{l}\text { Domingues et al., } \\
\text { 2000a }\end{array}$ \\
\hline & \multirow[t]{6}{*}{ S. cerevisiae NCYC869-A3/pVK1.1 } & SSlactose $1 \%{ }^{*}$ & $350 \mathrm{U} / \mathrm{mL}$ & Domingues et al., \\
\hline & & SSlactose $5 \%{ }^{* *}$ & $2000 \mathrm{U} / \mathrm{mL}$ & 2002 \\
\hline & & SSlactose $10 \%{ }^{* *}$ & $5096 \mathrm{U} / \mathrm{mL}$ & \\
\hline & & $\begin{array}{l}\text { Cheese whey permeate } 5 \% \text { lactose }{ }^{* *} \\
\left({ }^{*} \text { shake flasks, }{ }^{* *} 2 \text {-L bioreactor) }\right.\end{array}$ & $2635 \mathrm{U} / \mathrm{mL}$ & \\
\hline & & SSlactose $15 \%+1.5 \%$ YE (10-L bioreactor) & $7350 \mathrm{U} / \mathrm{mL}$ & $\begin{array}{l}\text { Domingues et al., } \\
2004\end{array}$ \\
\hline & & SSlactose 5\% (6-L airlift bioreactor) & Maximum: $3250 \mathrm{U} / \mathrm{mL}\left(\mathrm{D}=0.4 \mathrm{~h}^{-1}\right)$ & $\begin{array}{l}\text { Domingues et al., } \\
2005\end{array}$ \\
\hline & $\begin{array}{l}\text { S. cerevisiae } \mathrm{NCYC} 869 / \mathrm{p} \delta \text {-neo + lacA } \\
\text { cassette }\end{array}$ & SSlactose 5\% (6-L airlift bioreactor) & Maximum: $2754 \mathrm{U} / \mathrm{mL}\left(\mathrm{D}=0.1 \mathrm{~h}^{-1}\right)$ & $\begin{array}{l}\text { Oliveira et al., } \\
2007\end{array}$ \\
\hline \multirow[t]{15}{*}{ K. lactis } & S. cerevisiae LD1/YEplac118-LAC4 & YPD $2 \%$ glucose (shake flasks) & $17,000 \mathrm{U} / \mathrm{mL}$ & Becerra et al., 1997 \\
\hline & S. cerevisiae LHDP1/YEplac118-LAC4 & & $40,000 \mathrm{U} / \mathrm{mL}$ & \\
\hline & \multirow{2}{*}{$\begin{array}{l}\text { Six S. cerevisiae super-secreting } \\
\text { mutants } \\
\text { Plasmids: pSPGK1-LAC4; YEplac181-LAC4 }\end{array}$} & \multirow{2}{*}{$\begin{array}{l}\text { YPD } 2 \% \text { glucose } \\
\text { YPL } 4 \text { or } 6 \% \text { lactose (all shake flasks) }\end{array}$} & \multirow{2}{*}{$\begin{array}{l}\text { Highest secretion for CGY158/YEplac181- } \\
\text { LAC4: } 1700 \mathrm{U} / \mathrm{mL} \text { in YPD }\end{array}$} & \multirow{2}{*}{$\begin{array}{l}\text { Becerra et al., } \\
\text { 2001a }\end{array}$} \\
\hline & & & & \\
\hline & K. lactis MW 190-9B/pSPGK1-LAC4 & YPD $0.5 \%$ glucose & K. lactis MW 190-9B/pSPGK1-LAC4: & \multirow{5}{*}{$\begin{array}{l}\text { Becerra et al., } \\
\text { 2001b }\end{array}$} \\
\hline & \multirow[t]{4}{*}{ S. cerevisiae BJ3505/YEpFLAG1-LACA } & YPL 4\% lactose & -batch bioreactor, cheese whey permeate + & \\
\hline & & YPHSM & $1 \%$ YE: up to $25,000 \mathrm{U} / \mathrm{mL}$ & \\
\hline & & $\begin{array}{l}\text { Cheese whey permeate } 5 \% \text { lactose }+1 \% \mathrm{YE} \\
\text { (shake flasks and } 2 \text {-L bioreactor) }\end{array}$ & $\begin{array}{l}\text {-continuous bioreactor, YPL + } 0.1 \% \\
\text { glucose: } 150,000 \mathrm{U} / \mathrm{mL}\end{array}$ & \\
\hline & & & $\begin{array}{l}\text { S. cerevisiae BJ3505/YEpFLAG1-LACA: } \\
\text {-optimization in shake-flaks, YPHSM: } \\
20,440 \mathrm{U} / \mathrm{mL}\end{array}$ & \\
\hline & \multirow[t]{3}{*}{ S. cerevisiae BJ3505/YEpFLAG1-LAC4 } & YPL 4 or $6 \%$ lactose & YPL 4\% lactose: up to $2000 \mathrm{U} / \mathrm{mL}$ & \multirow[t]{3}{*}{ Becerra et al., 2002} \\
\hline & & Cheese whey permeate $+1 \%$ YE & YPL 6\% lactose: up to $1500 \mathrm{U} / \mathrm{mL}$ & \\
\hline & & (all shake flasks) & $\begin{array}{l}\text { Optimization in cheese whey permeate }+1 \% \\
\text { YE: } 8440 \mathrm{U} / \mathrm{mL}\end{array}$ & \\
\hline & S. cerevisiae LD1/YEplac181-LAC4 & YPD 2\% glucose & Higher yields for $S$. cerevisiae & \multirow[t]{3}{*}{ Becerra et al., 2004} \\
\hline & \multirow[t]{2}{*}{ S. cerevisiae LHDP1/YEplac181-LAC4 } & YPL 4 or $6 \%$ lactose & LHDP1/YEplac181-LAC4: up to $500 \mathrm{U} / \mathrm{mL}$ & \\
\hline & & $\begin{array}{l}\text { Cheese whey permeate } 5 \% \text { lactose } \\
\text { (all shake flasks) }\end{array}$ & & \\
\hline $\begin{array}{l}\text { K. lactis and } \\
\text { A. niger }\end{array}$ & $\begin{array}{l}\text { K. lactis MW 190-9B/pSPGK1-LAC4; } \\
\text { pSPGK1-LAC4-LACA }\end{array}$ & $\begin{array}{l}\text { Culture medium is not described } \\
\text { (shake flasks) }\end{array}$ & $\begin{array}{l}\text { K. lactis/pSPGK1-LACA: up to } 100 \mathrm{U} / \mathrm{mL} \\
\text { K. lactis/pSPGK1-LAC4-LACA: up to } 100-200 \mathrm{U} / \mathrm{mL}\end{array}$ & $\begin{array}{l}\text { Rodríguez et al., } \\
2006\end{array}$ \\
\hline
\end{tabular}

lactose concentrations (between 0.5 and $15 \%(\mathrm{w} / \mathrm{v})$ ), as well as with increasing yeast extract concentrations (between 0.2 and $1.5 \%(\mathrm{w} / \mathrm{v})$ ). It is worth noting that the recombinant $\beta$-galactosidase activity produced in medium containing $10 \%(\mathrm{w} / \mathrm{v})$ lactose was comparable to that obtained from A. niger but presented higher purity (Domingues et al., 2002). In the same work, cheese whey permeate was successfully used for recombinant $\beta$-galactosidase production, with rapid and complete lactose metabolization (less than $40 \mathrm{~h}$ ). Thus, this recombinant system allows for the bioremediation of cheese whey and $\beta$-galactosidase production simultaneously. Using optimized operation and culture conditions a 21 -fold increase in $\beta$-galactosidase production was attained in a 10-L bioreactor, comparing with the previous fermentations conducted in Erlenmeyer flasks (Domingues et al., 2004; Table 1). The percentage of $\beta$-galactosidase secreting cells at the end of fermentations was greater than $70 \%$. The continuous production of recombinant $\beta$-galactosidase was conducted in a high-cell-density 6-L airlift bioreactor (Domingues et al., 2005; Table 1). As occurred in batch fermentations, rapid and complete lactose consumption was observed with the simultaneous production of ethanol at concentrations close to the maximal theoretical values $(25 \mathrm{~g} / \mathrm{L})$. The higher $\beta$-galactosidase productivity $\left(6.2 \times 10^{5} \mathrm{U} / \mathrm{L} / \mathrm{h}\right)$ was obtained when operating at a dilution rate of $0.24 \mathrm{~h}^{-1}$. This system allowed an 11-fold increase in $\beta$-galactosidase productivity when compared to the batch system, using the same medium with the same lactose concentration. However, at higher dilution rates plasmid stability was low and, consequently, the $\beta$ galactosidase productivity decreased. To overcome this limitation, the lacA expression cassette was integrated in the $\delta$-sequences of the genome of the flocculating yeast strain S. cerevisiae NCYC869 (wildtype) (Oliveira et al., 2007). The use of the $\delta$-system together with G418 (geneticin) antibiotic selection resulted in flocculating $S$. cerevisae strains producing extracellular recombinant $\beta$-galactosidase at levels comparable to the multicopy plasmid system in flask cultures. Under the same airlift bioreactor operating conditions, the best integrant strain obtained (carrying approximately eight lacA gene copies) had similar $\beta$ galactosidase production to the strain carrying the pVK1.1 vector but was much more stable ( $95 \%$ and $40 \%$ of plasmid stability, respectively) (Oliveira et al., 2007; Table 1). Therefore, the integrant strain presents important advantages over the previously constructed strains for continuous A. niger $\beta$-galactosidase production.

\subsubsection{Heterologous production of $K$. lactis $\beta$-galactosidase}

The $K$. lactis $\beta$-galactosidase (encoded by the LAC4 gene) has a high biotechnological interest in the food industry and in cheese whey reutilization. The advantage of $K$. lactis over $A$. niger is that the yeast produces higher quantity of enzymatic units. However, due to its intracellular nature, the industrial production and application of $K$. lactis $\beta$-galactosidase is limited by the costs associated with its extraction and downstream processing. Therefore, two strategies have been adopted to secrete $K$. lactis $\beta$-galactosidase in yeast: (i) using yeast strains with the capacity of spontaneous lysis and (ii) using heterologous secretion signal sequences for extracellular production. In both cases, episomal plasmids were used for the cloning and expression of recombinant $K$. lactis $\beta$-galactosidase. 
(i) Two S. cerevisiae osmotic-remedial thermosensitive autolytic mutants have been employed to produce and release K. lactis $\beta$ galactosidase into the culture medium (Becerra et al., 1997; Becerra et al., 2004). In this way, 63 and $83 \%$ of total recombinant $\beta$-galactosidase activity could be detected in YPD medium (yeast extract peptone dextrose medium) after osmotic shock of the yeast cells from each strain, respectively (Becerra et al., 1997). The maximum extracellular $\beta$-galactosidase activity obtained corresponded to $63 \%$ of release (Table 1 ). In this case, plasmid stability at the end of the culture was about $70 \%$.

(ii) Different recombinant yeast strains able to secrete $K$. lactis $\beta$-galactosidase into the culture medium have been constructed. The secretion signal of the $K$. lactis killer toxin was used to secrete $K$. lactis $\beta$-galactosidase in a $K$. lactis strain mutated in the lac4 gene (Becerra et al., 2001b; Rodríguez et al., 2006). That same signal sequence and the Saccharomyces $\alpha$-factor have both been used to secrete $K$. lactis $\beta$-galactosidase in different $S$. cerevisiae strains (Becerra et al., 2001a; Becerra et al., 2001b; Becerra et al., 2002; Becerra et al., 2004). However, in all these works only partial secretion of recombinant $\beta$-galactosidase was achieved in the culture medium. Nevertheless, the constructed strains were able to grow on lactose as sole carbon source. Different constructions and culture conditions were experimented to improve heterologous secretion of $K$. lactis $\beta$-galactosidase. S. cerevisiae super-secreting mutants, together with the secretion signal of the $K$. lactis killer toxin, were used with that purpose but the maximum recombinant $\beta$-galactosidase activity detected in the culture medium corresponded only to $0.83 \%$ of secretion (Becerra et al., 2001a; Table 1). Although recombinant strains have grown well in YPL medium (yeast extract peptone lactose medium), the $\beta$-galactosidase activity and plasmid stability were considerably lower in this medium than in YPD medium (plasmid stability of the best secreting strain: 75\% in YPD (120 h) and 43\% in YPL (168 h)). An experimental factorial design was implemented to increase the secretion of heterologous $\beta$-galactosidase in a $S$. cerevisiae strain, using the $\alpha$-factor signal sequence (Becerra et al., 2001b; Becerra et al., 2002). Cheese whey permeate, YPD and YPHSM (YPD medium plus glycerol and calcium chloride) media were used and the best results were obtained with YPD medium followed by YPHSM medium (Becerra et al., 2001b). The extracellular enzyme activity obtained in YPHSM medium at the determined optimal culture conditions (temperature: $23^{\circ} \mathrm{C}$; aeration: $2 \mathrm{rpm} / \mathrm{mL}$; $\mathrm{NaCl}$ : 0\%; time: $72 \mathrm{~h}$ ) led to an 8 -fold increase in $\beta$-galactosidase secretion (Becerra et al., 2001b; Table 1). The production of extracellular recombinant $\beta$-galactosidase by the lac4 mutated $K$. lactis strain was conducted in a 2 -L bioreactor in both batch and continuous conditions, using different media (Becerra et al., 2001b). The higher extracellular recombinant $\beta$-galactosidase activity was obtained in continuous chemostat culture $\left(\mu=0.02 \mathrm{~h}^{-1}\right.$ ) and corresponded to $6.64 \%$ of enzyme secretion (Becerra et al., 2001b). Plasmid stability was $75 \%$ under these conditions. Interestingly, the percentage of secretion by $K$. lactis was improved by direct mutagenesis of the $\mathrm{N}$-terminal of the protein (Becerra et al., 2001b). To further improve secretion of heterologous $\beta$-galactosidase in $K$. lactis two hybrid proteins between $K$. lactis and $A$. niger $\beta$-galactosidases were constructed (Rodríguez et al., 2006). The secretion signal of the $K$. lactis killer toxin was fused to the $\mathrm{N}$-terminal of each hybrid protein to allow their secretion. A hybrid enzyme with improved secretion was obtained by replacing the $\mathrm{C}$-terminal five domains of $K$. lactis $\beta$-galactosidase with the corresponding five domains of A. niger $\beta$-galactosidase. Nevertheless, the activity levels of the hybrid and native $\beta$-galactosidases obtained in that work (Rodríguez et al., 2006) were lower than that obtained previously for the native enzyme using the same yeast strain and plasmid (Becerra et al., 2001b).

\subsection{Recombinant expression of bacterial $\beta$-galactosidases}

The most commonly known bacterial $\beta$-galactosidase is that from E. coli (encoded by the lacZ gene). This enzyme has similar properties to that of $K$. lactis and is also cytosolic, therefore its intracellular production is also not biotechnologically attractive. Moreover, this enzyme is not considered suitable for application in the food industry due to toxicity problems associated with the host coliform. The lacZ gene has been cloned in different recombinant yeast expression systems mainly to function as a reporter gene rather than for heterologous $\beta$-galactosidase production (e.g. Casadaban et al., 1983; Guarente, 1983). Nevertheless, several attempts were initially made to produce E. coli $\beta$-galactosidase in a secreted form in $S$. cerevisiae, using different yeast secretion signal sequences and fusion partners, although with little success (e.g. Vanoni et al., 1989; Venturini et al., 1997). Efficient secretion was achieved in this yeast using the signal sequence of GgPI (the major yeast glycosylphosphatidylinositol-containing protein) (Pignatelli et al., 1998). In addition, $E$. coli $\beta$-galactosidase was released in recombinant $S$. cerevisiae strains using spontaneous lysis strategies or the chemical permeabilization of the cells (Compagno et al., 1993; Porro et al., 1992).

Several other bacterial $\beta$-galactosidases have been cloned and expressed in different expression systems and host organisms, especially in recent years (summarized in Table 2). It is worth noting the increasing interest in the heterologous expression of bacterial $\beta$-galactosidases with novel optimal properties. Recent examples are the $\beta$-galactosidases from thermophilic Caldicellulosiruptor saccharolyticus (Park and Oh, 2010a), thermoacidophilic Alicyclobacillus acidocaldarius (Di Lauro et al., 2008; Yuan et al., 2008), hyperthermophilic Thermotoga maritima (Li et al., 2009a) and cold-adapted Alkalilactibacillus ikkense (Schmidt and Stougaard, 2010), among many others. Thermostable $\beta$-galactosidases have been attracting much attention owing to their many advantages for industrial use, including high reaction velocities, reduced risk of contamination, long half-lives, low product inhibition, high solubility of substrates and high yields (Chen et al., 2009; Park and Oh, 2010a). In addition, these new enzymes may be used during product processing, such as pasteurization (thermophilic ones) or refrigeration (cold-adapted ones). Bacterial $\beta$-galactosidases are either intracellular or expressed at low-levels and for these reasons their heterologous expression is highly desirable. However, in most of the reports found in the literature E. coli is used as expression host and the main goal is the cloning and characterization of the recombinant $\beta$-galactosidases (intracellularly produced) (Table 2). Nevertheless, higher yields of pure and functional enzyme than that obtained from the natural sources are frequently reported, especially when fusion partners are used for purification, as hereafter exemplified. The thermostable $\beta$-galactosidase from Thermus sp. strain T2 was overexpressed and purified in E. coli as a His(six-histidine)-tag fusion protein (Pessela et al., 2003; Table 2). Almost 3 orders of magnitude of more enzyme activity was obtained than that produced by the Thermus strain. To improve the recombinant enzyme purification a selective one-point adsorption was achieved by designing tailor-made low-activated Co-IDA or Ni-IDA supports, which resulted in more than $90 \%$ of recovery of stable enzyme. The fusion tag did not affect the activation, kinetics parameters and stability of the recombinant $\beta$-galactosidase. Interestingly, recombinant fusion and non-fusion $\beta$-galactosidases presented very close $K_{m}$ values at $\mathrm{pH} 6.5$ and $70{ }^{\circ} \mathrm{C}$, but the fusion enzyme showed a significant activity at $\mathrm{pH} 4.0$, while the native was inactive at this $\mathrm{pH}$. Another thermostable $\beta$-galactosidase (from A. acidocaldarius) was cloned and expressed in E. coli as a fusion protein with the Schistosoma japonicum glutathione $S$-transferase (GST) gene. About $10 \mathrm{mg}$ of pure recombinant protein, optimally active and stable a $65^{\circ} \mathrm{C}$, was obtained from $1 \mathrm{~L}$ of $E$. coli culture, whereas $20 \mathrm{~L}$ of $A$. acidocaldarius culture was needed to obtain $5 \mathrm{mg}$ of pure native enzyme (Di Lauro et al., 2008; Table 2). After removal of the GST portion, the recombinant enzyme showed a specific activity 1.5 -fold higher than that of the native enzyme, probably due to its higher purity. 
Table 2

Summary of recent reports on the heterologous expression and purification of bacterial $\beta$-galactosidases in other hosts.

\begin{tabular}{|c|c|c|c|}
\hline Source of the enzyme & Expression host & Culture volume and $\beta$-galactosidase purification yield & References \\
\hline \multirow[t]{2}{*}{ Alicyclobacillus acidocaldarius $^{\mathbf{a}}$} & Escherichia coli & $1 \mathrm{~L}: 10 \mathrm{mg} ; 8680 \mathrm{U}$ & Di Lauro et al., 2008 \\
\hline & Pichia pastoris & $4 \mathrm{~L}: 1.8 \mathrm{mg} ; 454 \mathrm{U}$ & Yuan et al., 2008 \\
\hline Alkalilactibacillus ikkense $\mathbf{b}^{\mathbf{b}}$ & E. coli & $200 \mathrm{~mL}: 2.5 \mathrm{mg} ; 21 \mathrm{U}$ & Schmidt and Stougaard, 2010 \\
\hline \multirow[t]{2}{*}{ Antarctic Arthrobacter sp. $32 c^{\mathbf{b}}$} & E. coli & $1 \mathrm{~L}: 27 \mathrm{mg} ; 4209 \mathrm{U}$ & Hildebrandt et al., 2009 \\
\hline & P. pastoris & $1 \mathrm{~L}: 137 \mathrm{mg} ; 21,194 \mathrm{U}$ & \\
\hline Bacillus stearothermophilus ${ }^{\mathbf{a}}$ & B. subtilis & n.r.: $209 \mathrm{mg} ; 26,200 \mathrm{U}$ & Chen et al., 2008 \\
\hline Bifidobacterium infantis ${ }^{\mathbf{a}}$ & E. coli & n.r.: $6.5 \mathrm{mg} ; 3697 \mathrm{U}$ & Hung and Lee, 2002 \\
\hline Caldicellulosiruptor saccharolyticus ${ }^{\mathbf{a}}$ & E. coli & n.r.: $3.2 \mathrm{mg} ; 678 \mathrm{U}$ & Park and $\mathrm{Oh}, 2010 \mathrm{a}^{\mathbf{c}}$ \\
\hline Enterobacter cloacae & E. coli & 2 L: purification data n.r. & Lu et al., $2009^{c}$ \\
\hline Lactobacillus acidophilus $^{\mathbf{a}}$ & E. coli & n.r.: $7.34 \mathrm{mg} ; 317 \mathrm{U}$ & Pan et al., 2010 \\
\hline \multirow[t]{2}{*}{ L. acidophilus, L. plantarum, L. reuteri, L. sakei } & $\begin{array}{l}\text { L. plantarum } \\
\text { L. sakei }\end{array}$ & $1 \mathrm{~L}: 245 \mathrm{U} / \mathrm{mg}$ (L. reuteri enzyme in L. plantarum) & Halbmayr et al., 2008 \\
\hline & Lactococcus lactis & $1170-14,000 \mathrm{U} / \mathrm{L}$ of culture (purification not performed) & Maischberger et al., 2010 \\
\hline Lactobacillus delbrueckii subsp. bulgaricus & E. coli & Purification data n.r. & Rhimi et al., 2009 \\
\hline L. plantarum & L. plantarum & $50 \mathrm{~mL}: 1.7 \mathrm{mg} ; 265 \mathrm{U}$ & Iqbal et al., 2010 \\
\hline L. reuteri & E. coli & $1 \mathrm{~L}: 461 \mathrm{mg} ; 83,000 \mathrm{U}$ & Nguyen et al., $2007^{c}$ \\
\hline Paenibacillus thiaminolyticus & E. coli & $1 \mathrm{~L}$ : purification data n.r. & Benešová et al., $2010^{c}$ \\
\hline Pseudoalteromonas & E. coli & $1 \mathrm{~L}: 13.8 \mathrm{mg} ; 1490 \mathrm{U}$ & Cieśliński et al., 2005 \\
\hline Pyrococcus woese $i^{\text {a }}$ & E. coli & $1 \mathrm{~L}: 28 \mathrm{mg} ; 151,200 \mathrm{U}$ & Dąbrowski et al., $2000^{c}$ \\
\hline Rhizobium meliloti & E. coli & $1 \mathrm{~L}: 4.86 \mathrm{mg} ; 269 \mathrm{U}$ & Leahy et al., 2001 \\
\hline Streptococcus mitis & E. coli & $2 \mathrm{~L}: 8.2 \mathrm{mg} ; 24,350 \mathrm{U}$ & Campuzano et al., 2009c \\
\hline \multirow[t]{2}{*}{ Thermotoga maritima } & E. coli & $500 \mathrm{~mL}: 7.6 \mathrm{mg} ; 530 \mathrm{U}$ & Kim et al., $2004^{c}$ \\
\hline & & $100 \mathrm{~mL}: 40.4 \mathrm{mg} ; 873 \mathrm{U}$ & Li et al., 2009ac \\
\hline \multirow[t]{2}{*}{ Thermus $s p .^{\mathbf{a}}$} & E. coli & $150 \mathrm{~mL}$ : purification data n.r. & Kang et al., $2005^{\mathbf{c}}$ \\
\hline & & $1 \mathrm{~L}: 900,000-958,000 \mathrm{U} / \mathrm{mg}$ & Pessela et al., $2003^{c}$ \\
\hline
\end{tabular}

n.r. - not reported.

a Thermophilic enzymes.

b Cold-adapted enzymes.

c His-tagged recombinant enzymes.

Bacterial $\beta$-galactosidases have also been cloned and expressed in Bacillus subtilis (Chen et al., 2008; Xia et al., 2010). The thermostable $\beta$-galactosidase from Bacillus stearothermophilus was expressed in $B$. subtilis to overcome the lower enzymatic half-life at $60{ }^{\circ} \mathrm{C}$ (just $0.5 \mathrm{~h}$ ) presented by the homologous recombinant enzyme previously expressed in E. coli (Chen et al., 2008). Thermostable recombinant $\beta$ galactosidase was successfully expressed in $B$. subtilis and the specific enzymatic activity was more than 45 times of that obtained from $B$. stearothermophilus (Hirata et al., 1986). A two-step purification procedure, consisting on anion exchange plus gel filtration, was used to recover the recombinant enzyme from the cell-free protein extracts (Chen et al., 2008; Table 2). It is worth noting that a recombinant bacterial $\beta$-galactosidase (from Geobacillus stearothermophilus) has been recently expressed in a secreted form in B. subtilis when it was fused to a twinarginine signal peptide of B. subtilis phosphodiesterase (Xia et al., 2010).

Lactobacillus species were employed aiming an efficient food-grade overproduction of four Lactobacillus $\beta$-galactosidases (Halbmayr et al., 2008). Halbmayr et al. could inducibly overexpress and purify Lactobacillus $\beta$-galactosidases in Lactobacillus plantarum and Lactobacillus sakei, using a bacteriocin(sakacin P)-based expression system (Table 2). The highest expression level was obtained for the recombinant Lactobacillus reuteri $\beta$-galactosidase expressed in $L$. plantarum. Cultivation in a 1-L bioreactor yielded approximately 23,000 $\mathrm{U}$ of $\beta$-galactosidase activity, which was considerably higher (9-folds) than the maximal yield reported for the wild-type $L$. reuteri strain. The recombinant enzyme was purified from the cell-free protein extracts in a single purification step using affinity chromatography on $p$-aminobenzyl-1-thio-B-D-galactopyranoside agarose, which was clearly more efficient than the three-step purification protocol described for the purification of the native enzyme. Properties of the purified recombinant $\beta$-galactosidase were found to be essentially the same as those of the native enzyme or the recombinant enzyme produced in E. coli. However, in that study the selective pressure of the cultures was still based on antibiotic resistance (erythromycin). To improve the food-grade production of Lactobacillus $\beta$-galactosidases, Maischberger et al. (2010) overexpressed the same enzymes in Lactococcus lactis using the food- grade nisin-controlled expression system NICE and plasmid selection based on the ability to grow on lactose (Table 2). In this way, $8400 \mathrm{U} / \mathrm{L}$ of fermentation medium of recombinant $L$. reuteri $\beta$-galactosidase activity was obtained, which was also considerably higher than that obtained with the original host $(2500 \mathrm{U} / \mathrm{L})$. This food-grade recombinant expression system is more advantageous than the previous one as it yielded more recombinant $\beta$-galactosidase under the same cultivation conditions ( $50 \mathrm{~mL}$ flask cultures), using a food-grade inducer (nisin) and without the need of antibiotics for selective pressure. The purification and the characterization of the recombinant enzyme were not reported; nevertheless, the application of the GRAS host together with the foodgrade expression system was suggested for the production of lactosefree products or novel prebiotic GOS (Maischberger et al., 2010).

The methylotrophic yeast Pichia pastoris was employed to produce two bacterial $\beta$-galactosidases aiming at their industrial application. The thermostable $\beta$-galactosidase from $A$. acidocaldarius (Yuan et al., 2008) and the cold-adapted $\beta$-galactosidase from Antarctic Arthrobacter sp. 32c (Hildebrandt et al., 2009) were successfully expressed in a secreted form in this heterologous host, making use of the Saccharomyces $\alpha$-factor signal sequence. The major advantage of secreting recombinant proteins in P. pastoris is that this yeast secretes very low levels of native proteins, which facilitates the purification of the recombinant protein. The amount of recombinant $A$. acidocaldarius thermostable $\beta$-galactosidase secreted in $P$. pastoris shake-flask cultures $(90 \mathrm{mg} / \mathrm{L})$ was higher than that expressed naturally (Yuan et al., 2008). Furthermore, this recombinant overexpression system was more efficient than the E. coli expression system (10-70 mg/L; Di Lauro et al., 2008). Nevertheless, the three-step purification procedure adopted for the purification of the recombinant enzyme from the P. pastoris supernatants allowed only $6.7 \%$ of enzyme recovery, which was considerably lower than that obtained from $E$. coli (Table 2). Note that the genes encoding A. acidocaldarius $\beta$-galactosidase cloned in each recombinant expression system were different but shared $97 \%$ of identity (E. coli: lacB gene; P. pastoris: Bgly gene). The $\mathrm{pH}$ and temperature optima of the recombinant enzyme produced in P. pastoris were similar to that of the native enzyme (5.8 and $70{ }^{\circ} \mathrm{C}$, respectively). 
Using constitutive or inducible P. pastoris expression systems, higher amounts of pure recombinant Antarctic Arthrobacter $\beta$-galactosidase were obtained than using the $E$. coli expression system (Hildebrandt et al., 2009; Table 2). Affinity chromatography on $p$-aminobenzyl-1thio- $\beta$-D-galactopyranoside agarose was used for the purification of the recombinant enzymes. The authors considered the $P$. pastoris system a high efficient and cheap way to produce this cold-adapted enzyme extracellularly (cost of $1 \mathrm{mg}$ of purified enzyme was estimated at $0.03 €)$. Nevertheless, its optimal activity was determined at $50{ }^{\circ} \mathrm{C}(\mathrm{pH}$ 6.5 ) and only $15 \%$ to $20 \%$ of maximum activity was detected in the $0-10{ }^{\circ} \mathrm{C}$ temperature range. Similarly, the cold-adapted Pseudoalteromonas $\beta$-galactosidase expressed and purified from $E$. coli cells also retained just $20 \%$ of maximum activity at $10{ }^{\circ} \mathrm{C}$ (Cieśliński et al., 2005). On the other hand, the cold-adapted $A$. ikkense $\beta$-galactosidase produced and purified from the same bacterial expression system was much more active and stable at low temperatures. This recombinant enzyme maintained more than $60 \%$ of its activity at $0{ }^{\circ} \mathrm{C}$ and was stable for more than $100 \mathrm{~h}$ at temperatures of $10^{\circ} \mathrm{C}$ or below, without the use of stabilizing agents (Schmidt and Stougaard, 2010).

\subsection{Applications of recombinant $\beta$-galactosidases}

The $\beta$-galactosidase enzymes produced by means of recombinant DNA technology present several advantages in terms of the production and purification processes. Moreover, recombinant enzymes with improved properties may be obtained. Nevertheless, the evaluation of their applications has only been reported for some of them.

\subsubsection{Milk lactose hydrolysis}

The traditional use of $\beta$-galactosidase in dairy industry has been the hydrolysis of lactose in milk (Fig. 1). Curiously, most of the reports on the use of recombinant $\beta$-galactosidases are related with this application.

The Pseudoalteromonas cold-adapted $\beta$-galactosidase enzyme, produced and purified from E. coli cells (Cieśliński et al., 2005; Table 2), was applied in the hydrolysis of lactose in a milk assay where $90 \%$ of milk lactose was hydrolyzed for $6 \mathrm{~h}$ at $30^{\circ} \mathrm{C}$. The advantage of this recombinant enzyme is that it can be used at lower temperatures hydrolyzing $90 \%$ of milk lactose in $28 \mathrm{~h}$ at $15{ }^{\circ} \mathrm{C}$. Recombinant coldadapted $L$. acidophilus $\beta$-galactosidase (Pan et al., 2010; Table 2), produced and purified also from the $E$. coli expression system, hydrolyzed $73 \%$ of lactose in milk in $30 \mathrm{~h}$ at $10{ }^{\circ} \mathrm{C}$ (Pan et al., 2010).

A couple of thermophilic $\beta$-galactosidase enzymes encoding genes have also been cloned in different expression hosts and tested for the hydrolysis of milk lactose. The use of thermophilic $\beta$-galactosidases may prevent microbial contamination to some extent in milk processing, functioning under conditions that normally denature mesophilic enzymes. As a consequence, its expression in hosts that enable production on an industrial scale has become of interest. The Pyrococcus woesei thermostable $\beta$-galactosidase, produced and purified from E. coli cells (Dąbrowski et al., 2000; Table 2), was characterized and displayed high activity and thermostability. For testing its application on lactose hydrolysis, the recombinant enzyme was immobilized in chitin and packed in a jacketed column. A study of continuous operation of the column was made at pH 5.4 in $0.01 \mathrm{M}$ phosphate citrate buffer with $5 \%$ lactose at $75{ }^{\circ} \mathrm{C}$ and a flow rate of $80 \mathrm{~mL} / \mathrm{h}$. Unexpectedly, the immobilized enzyme exhibited a relatively short half-life value ( $31 \mathrm{~h}$ ). Another more up to date example of recombinant thermostable $\beta$-galactosidase application in milk lactose hydrolysis is reported in the study conducted by Yuan et al. (2008) with the $\beta$-galactosidase from Alicyclobacillus acidocaldarius produced from the Pichia expression system (Table 2). Approximately $48 \%$ of lactose in milk was hydrolyzed following treatment with the recombinant enzyme over $60 \mathrm{~min}$ at $65^{\circ} \mathrm{C}$, while the hydrolysis rate was significantly higher in a lactose solution under the same conditions. The authors attributed the discrepancy between lactose hydrolysis in milk and lactose solution to inhibitory effects of other components in milk. Another recent example, is the very interesting thermostable recombinant $\beta$-galactosidase enzyme from $B$. stearothermophilus (Chen et al., 2008; Table 2) used for lactose hydrolysis in milk (Chen et al., 2009). The enzyme characterization revealed that the recombinant $\beta$-galactosidase was active at high temperatures up to $75^{\circ} \mathrm{C}$ and displayed elevated thermostability as well. The enhanced stability properties, combined with its neutral pH activity and favorable temperature activity optimum, suggest that this enzyme is an ideal candidate for the hydrolysis of lactose in milk, and would be suitable for application in low-lactose milk production during milk pasteurization (Chen et al., 2008). In fact, the recombinant enzyme (at a concentration of $2 \mathrm{U} / \mathrm{mL}$ ) hydrolyzed $100 \%$ milk lactose at $65{ }^{\circ} \mathrm{C}$ for $100 \mathrm{~min}$ (Chen et al., 2008). Moreover, the recombinant thermostable $\beta$-galactosidase possessed a high level of transgalactosylation activity in parallel with the hydrolysis of lactose in milk. Oligosaccharides are no longer considered as undesired products as in early times (see Shuklaa and Wierzbickib, 1975) but its presence in low-lactose milk is nowadays regarded as a valuable trait. Indeed, GOS produced via the transgalactosylation activity of $\beta$-galactosidase are utilized as growthpromoting substrates of bifidobacteria in the human intestine (Park and $\mathrm{Oh}, 2010 \mathrm{~b})$. The recombinant thermostable $\beta$-galactosidase from B. stearothermophilus was immobilized onto chitosan using Tris (hydroxymethyl)phosphine (THP) and glutaraldehyde, and a packed bed reactor was utilized to hydrolyze lactose in milk (Chen et al., 2009). The THP-immobilized enzyme displayed better enzyme activity, reusability, thermostability, and storage stability compared with free and glutaraldehyde-immobilized enzymes. More than $80 \%$ of lactose hydrolysis was achieved after $2 \mathrm{~h}$ of operation at $70{ }^{\circ} \mathrm{C}$ in a packed-bed reactor with THP-immobilized $\beta$-galactosidase (Chen et al., 2009).

The recombinant acidotolerant $\beta$-galactosidase from Lactobacillus delbrueckii subsp. bulgaricus ATCC 11842, produced from the E. coli expression system, has been explored for lactose hydrolysis (Rhimi et al., 2009; Table 2). Biochemical characterization of the purified protein revealed optimal activity in a wide temperature range $\left(35\right.$ to $\left.50{ }^{\circ} \mathrm{C}\right)$ and at $\mathrm{pH}$ values comprised between 5.0 and 5.5. Interestingly, primary structure alignment suggested that only acidotolerant enzymes including that of $L$. bulgaricus have glutamic acid at position 491. Making use of the E. coli recombinant system and site-directed mutagenesis a modified version of the recombinant enzyme was produced: the glutamic acid at position 491 was replaced by alanine (E491A). The biochemical characterization revealed that the E491A mutation did not affect the kinetic parameters and temperature profile of the protein but the $\mathrm{pH}$ optima profile was undoubtedly shifted from 5.0-5.5 for the wild-type enzyme to 6.5-7.0 for the modified enzyme. When comparing lactose hydrolysis rates both in milk and whey, the original version was more efficient for whey hydrolysis ( $88 \%$ bioconversion at $42{ }^{\circ} \mathrm{C}$ after $10 \mathrm{~h}$ with $1 \mathrm{mg} / \mathrm{mL} \beta$-galactosidase against $60 \%$ for the mutated version in the same conditions) while the mutated version was more efficient in milk lactose hydrolysis ( $89 \%$ bioconversion at $42{ }^{\circ} \mathrm{C}$ after $10 \mathrm{~h}$ with $1 \mathrm{mg} / \mathrm{mL}$ $\beta$-galactosidase against $80 \%$ for the original version).

\subsubsection{Whey bioremediation}

Several alternatives have been proposed for the treatment and valorization of cheese whey (reviewed in Guimarães et al., 2010) with some of them involving the use of the $\beta$-galactosidase enzyme (Fig. 1). However, there are very few reports on the use of recombinant enzymes concerning this application. One is the above mentioned acidotolerant $\beta$-galactosidase from L. bulgaricus produced and purified from E. coli cells. Typically, fungal $\beta$-galactosidases have acidic pH-optima and thus they are most effective for the hydrolysis of lactose present in acidic products such as whey. The industrially relevant $\beta$-galactosidase from $A$. niger has been produced in flocculent S. cerevisiae cells (see Section 2.1.1) and applied in whey hydrolysis. In a preliminary assay, the produced recombinant enzyme was ultrafiltrated and applied directly for whey 
hydrolysis ( $0.5 \mathrm{~mL}$ enzyme sample to $10 \mathrm{~mL}$ of whey-permeate solution) achieving $90 \%$ lactose bioconversion in $20 \mathrm{~h}$ at $30{ }^{\circ} \mathrm{C}$ (Domingues et al., 2003). This recombinant system could be of interest for the dairy industry as the recombinant $\beta$-galactosidase was secreted from flocculent $S$. cerevisiae cells at the same time as ethanol was produced while using whey permeate as substrate (Domingues et al., 2002). Moreover, with a simple ultrafiltration step the produced enzyme could be easily applied for lactose bioconversion. Nevertheless, further research on lactose hydrolysis by this enzyme is needed.

\subsubsection{Biosensors and fusion proteins}

Recombinant $\beta$-galactosidase (normally, E. coli $\beta$-galactosidase) has been extensively used as a fusion protein in different fields due to its easy detection (Caubín et al., 2001; Huang et al., 2009). One of the most relevant applications is in biosensors. The expression and production of recombinant $\beta$-galactosidases have been determinants for the progress of this area. Several works can be found in literature concerning the use of recombinant $\beta$-galactosidases in biosensors construction and functionalization. One example is the use of a chimera protein made by the fusion of $\beta$-galactosidase from $E$. coli and the choline-binding domain of the (acetylmuramoyl)-L-alanine amidase from Streptococcus pneumoniae in the development of a specific immobilization method of proteins onto a gold electrode (Madoz et al., 1997). Also worth of noting is the application of recombinant fusion $\beta$-galactosidases in the development of allosteric biosensors. These specific biosensors allow detection of antibodies against different viruses by accommodating peptide sequences from surface viral proteins, acting as antibody receptors, into permissive sites of allosterically responsive recombinant $\beta$-galactosidases. Among the advantages of such biosensors as diagnostic tools is the homogeneous nature of the assay, the short time required for the enzymatic reaction and antibody detection, and the potential for handling large number of samples and for automatic processing, as shown for human immunodeficiency virus (Ferraz et al., 2006; Ferraz et al., 2008). More recently, allosteric biosensors for detection of the animal foot-and-mouth disease virus (FMDV) have been developed, allowing the differentiation between sera FMDV-infected animals and those of naïve and conventionally vaccinated ones (Sánchez-Aparicio et al., 2009).

As new enzymes are discovered and characterized by recombinant DNA technology, new biosensors are also described in literature. One recent example is a $\beta$-galactosidase having a modular structure with a choline-binding domain that has been identified for the first time in Streptococcus mitis (Campuzano et al., 2009; Table 2). The recombinant enzyme, produced from the E. coli expression system, presented negligible product inhibition by higher concentrations of glucose, weak inhibition by galactose in comparison with other $\beta$ galactosidases, high substrate specificity towards lactose and superior stability at room temperature. The authors state that they have under development for application in the dairy industry a promising integrated amperometric lactose biosensor which contains the recombinant $S$. mitis $\beta$-galactosidase, glucose oxidase, peroxidase, and tetrathiafulvalene coimmobilized by cross-linking with glutaraldehyde in a gold disk electrode modified with a 3-mercaptopropionic acid self-assembled monolayer (Campuzano et al., 2009).

\subsubsection{Other applications}

Besides their hydrolytic activity on lactose, $\beta$-galactosidase enzymes may also possess transgalactosylation activity which expands their potential applications (Fig. 1). The transferase activity enables not only the synthesis of GOS, increasingly documented as useful nutritional instruments for the modulation of colonic microflora towards a healthy balance, but can also be used to attach galactose to other chemicals and consequently have imminent applications in the production of biological active compounds (Panesar et al., 2006). Therefore, the search for new $\beta$-galactosidase enzymes with transferase activity and its expression and production from recombinant hosts in order to be able to characterize their GOS production has been progressively reported in literature. Recombinant thermostable T. maritima $\beta$-galactosidase, produced and purified from E. coli cells (Kim et al., 2004; Table 2), was used for GOS production (Ji et al., 2005). More recently, the characterization of the GOS produced by a $\beta$-galactosidase from $L$. plantarum has been reported (Iqbal et al., 2010; Table 2). The enzyme was efficiently overproduced in the homologous expression Lactobacillus system, presented a high transgalactosylation activity and was used for the synthesis of prebiotic GOS. Another example of newly isolated $\beta$-galactosidases with transferase activity is the one from Enterobacter cloacae B5, overexpressed from the E. coli expression system (Lu et al., 2009; Lu et al., 2010; Table 2). This recombinant enzyme was employed to synthesize novel galactose containing chemicals using galactosyl mannitol, galactosyl sorbose and galactosyl salicin as acceptors in the presence of 0 -nitrophenyl- $\beta$-D-galactopyranoside as donor (Lu et al., 2010). Some of the $\beta$-galactosidase enzymes are recognized to display not only $\beta$-D-galactosidase activity, but also the $\beta$-D-fucosidase, $\beta$-D-glucosidase, or $\alpha$-L-arabinosidase activity (Chang et al., 2009). Interestingly, Benešová et al. (2010) have identified a $\beta$-galactosidase with $\beta$-D-fucosidase activity from a genomic library of the bacterial strain Paenibacillus thiaminolyticus (Table 2). According to the reported results, this enzyme seems to be a promising tool for the synthesis of different types of $\beta$-D-fucosylated molecules with huge potential in biotechnology and pharmaceutical industry (Benešová et al., 2010).

\section{Concluding remarks and future trends}

In recent times, it is patent (meaning obvious) a raising trend for the isolation and characterization of novel $\beta$-galactosidase enzymes. The use of recombinant expression systems has been vital not only for this progress but also for large-scale production of the most interesting identified enzymes. Two trends can be distinguished: one related with the traditional hydrolytic activity of $\beta$-galactosidase where novel coldactive and also thermophilic enzymes have been described, and the other related with the characterization of innovative proteins with other activities besides the hydrolytic one. Even though $\beta$-galactosidase hydrolytic activity has been traditionally used in the dairy industry for obtaining lactose-free products there is still place for new developments. For instance, several cold-active $\beta$-galactosidases, which can be used to hydrolyze lactose to glucose and galactose from refrigerated milk at low temperature, have been identified and characterized. One recent interesting example is $\beta$-galactosidase from the psychrotolerant yeast Guehomyces pullulans 17-1 (Song et al., 2010). This yeast was isolated from sea sediment in Antarctica and produces $\beta$-galactosidase extracellularly. From the other side, the use of thermophilic enzymes in the production of lactose-hydrolyzed products also presents significant advantages when comparing with the traditional process, as above mentioned (Section 2.2). In the case of low-lactose milk, an important advantage is that the use of thermophilic enzymes enables lactose hydrolysis during the pasteurization process. Presumably, the use of these thermostable $\beta$-galactosidases, cold-active or thermophilic, will be progressively incorporated by the dairy industry. Due to the key role of GOS in the field of functional foods, $\beta$-galactosidases with transferase and other activities will undoubtedly draw most of the researcher's attention. Since the GOS products currently available on the market were not designed rationally, there is still need to find good microbial sources of $\beta$-galactosidases allowing high transgalactosylation activities, and to characterize the individual components of the GOS mixtures, obtained with these biocatalysts (Iqbal et al., 2010). Actually, this is a very active research field which will most probably continue to grow. In this context, recombinant production systems are crucial as the microbial sources of these $\beta$-galactosidase enzymes are usually not GRAS and may present tedious growth and productivities. Besides that, recombinant systems are also essential for generating improved versions of the enzymes. For instance, when changing arginine to triptophan at position 109 (R109W) on the $\beta$-galactosidase from G. stearothermophilus, the 
galacto-oligosaccharide yield from lactose and the productivity of GOS increased by approximately 12 - and 17 -folds, respectively (Placier et al., 2009). As in the transgalactosylation reaction glucose inhibition is a concern, a modified $\beta$-galactosidase at glucose- or galactose-binding site that shows reduced inhibition by glucose or galactose is highly desirable (Park and Oh, 2010b).

At present, it is worth noting that the synthetic capabilities of $\beta$-galactosidases are continuously expanding (Lu et al., 2010). Some $\beta$-galactosidases display broad substrate specificity together with the ability to transfer diverse monsaccharidic residues to different saccharidic or nonsaccharidic acceptors (Benešová et al., 2010). Recent reports show the effective enzymatic synthesis by $\beta$-galactosidase of different types of $\beta$-D-fucosylated molecules (Benešová et al., 2010), lactosucrose (Li et al., 2009b) and lactulose (Kim et al., 2006; Lee et al., 2004). In addition, more acceptors such as mannitol, sorbose, salicin, sorbitol and trehalose have also been found to be glycosylated by these enzymes to form novel chemicals (Kim et al., 2007; Klewicki, 2007a,b; Lu et al., 2010). Undoubtedly, the trend is that $\beta$-galactosidase enzymes will develop into promising synthetic tools.

\section{Acknowledgments}

C. Oliveira and P. M. R. Guimarães acknowledge support from Fundação para a Ciência e a Tecnologia (FCT), Portugal (grants SFRH/ BDP/63831/2009 and SFRH/BDP/44328/2008, respectively).

\section{References}

Adam AC, Rubio-Texeira M, Polaina J. Lactose: the milk sugar from a biotechnological perspective. Crit Rev Food Sci Nutr 2004;44:553-7.

Bailey RB, Benitez T, Woodward A. Saccharomyces cerevisiae mutants resistant to catabolite repression - use in cheese whey hydrolysate fermentation. Appl Environ Microbiol 1982;44:631-9.

Becerra M, Cerdán E, Siso MIG. Heterologous Kluyveromyces lactis beta-galactosidase production and release by Saccharomyces cerevisiae osmotic-remedial thermosensitive autolytic mutants. Biochim Biophys Acta 1997;1335:235-41.

Becerra M, Prado SD, Cerdán E, Siso MIG. Heterologous Kluyveromyces lactis betagalactosidase secretion by Saccharomyces cerevisiae super-secreting mutants. Biotechnol Lett 2001a;23:33-40.

Becerra M, Prado SD, Siso MIG, Cerdán ME. New secretory strategies for Kluyveromyces lactis beta-galactosidase. Protein Eng 2001b;14:379-86.

Becerra M, Prado SD, Rodríguez-Belmonte E, Cerdán ME, Siso MIG. Metabolic engineering for direct lactose utilization by Saccharomyces cerevisiae. Biotechnol Lett 2002;24:1391-6.

Becerra M, Rodríguez-Belmonte E, Esperanza Cerdán M, Gonzalez Siso MI. Engineered autolytic yeast strains secreting Kluyveromyces lactis beta-galactosidase for production of heterologous proteins in lactose media. J Biotechnol 2004;109:131-7.

Benešová E, Lipovová P, Dvořáková H, Králová B. Beta-D-galactosidase from Paenibacillus thiaminolyticus catalyzing transfucosylation reactions. Glycobiology 2010;20:442-51.

Campuzano S, Serra B, Llull D, García JL, García P. Cloning, expression, and characterization of a peculiar choline-binding beta-galactosidase from Streptococcus mitis. Appl Environ Microbiol 2009;75:5972-80.

Casadaban MJ, Martinez-Arias A, Shapira SK, Chou J. Beta-galactosidase gene fusions for analyzing gene expression in Escherichia coli and yeast. Methods Enzymol 1983;100:293-308.

Caubín J, Martín H, Roa A, Cosano I, Pozuelo M, de La Fuente JM, et al. Choline-binding domain as a novel affinity tag for purification of fusion proteins produced in Pichia pastoris. Biotechnol Bioeng 2001;74:164-71.

Chang A, Scheer M, Grote A, Schomburg I, Schomburg D. BRENDA, AMENDA and FRENDA the enzyme information system: new content and tools in 2009. Nucleic Acids Res 2009;37:D588-92.

Chen W, Chen H, Xia Y, Zhao J, Tian F, Zhang H. Production, purification, and characterization of a potential thermostable galactosidase for milk lactose hydrolysis from Bacillus stearothermophilus. J Dairy Sci 2008;91:1751-8.

Chen W, Chen H, Xia Y, Yang J, Zhao J, Tian F, et al. Immobilization of recombinant thermostable beta-galactosidase from Bacillus stearothermophilus for lactose hydrolysis in milk. J Dairy Sci 2009;92:491-8.

Cieśliński H, Kur J, Bialkowska A, Baran I, Makowski K, Turkiewicz M. Cloning, expression, and purification of a recombinant cold-adapted beta-galactosidase from antarctic bacterium Pseudoalteromonas sp 22b. Protein Expr Purif 2005;39:27-34.

Compagno C, Tura A, Ranzi BM, Martegani E. Bioconversion of lactose/whey to fructose diphosphate with recombinant Saccharomyces cerevisiae cells. Biotechnol Bioeng 1993:42:398-400.

Dąbrowski S, Sobiewska G, Maciuńska J, Synowiecki J, Kur J. Cloning, expression, and purification of the His(6)-tagged thermostable beta-galactosidase from Pyrococcus woesei in Escherichia coli and some properties of the isolated enzyme. Protein Expr Purif 2000;19:107-12.
Di Lauro B, Strazzulli A, Perugino G, La Cara F, Bedini E, Corsaro MM, et al. Isolation and characterization of a new family 42 beta-galactosidase from the thermoacidophilic bacterium Alicyclobacillus acidocaldarius: identification of the active site residues. Biochim Biophys Acta 2008;1784:292-301.

Domingues L, Dantas MM, Lima N, Teixeira JA. Continuous ethanol fermentation of lactose by a recombinant flocculating Saccharomyces cerevisiae strain. Biotechnol Bioeng 1999;64:692-7.

Domingues L, Onnela ML, Teixeira JA, Lima N, Penttilä M. Construction of a flocculent brewer's yeast strain secreting Aspergillus niger beta-galactosidase. Appl Microbiol Biotechnol 2000a;54:97-103.

Domingues L, Lima N, Teixeira JA. Contamination of a high-cell-density continuous bioreactor. Biotechnol Bioeng 2000b;68:584-7.

Domingues L, Teixeira JA, Penttilä M, Lima N. Construction of a flocculent Saccharomyces cerevisiae strain secreting high levels of Aspergillus niger beta-galactosidase. Appl Microbiol Biotechnol 2002;58:645-50.

Domingues L, Lima N, Teixeira J. An integrated approach for cheese whey lactose valorisation. Recent Res Devel Biotech Bioeng 2003;5:65-78.

Domingues L, Oliveira C, Castro I, Lima N, Teixeira JA. Production of beta-galactosidase from recombinant Saccharomyces cerevisiae grown on lactose. J Chem Technol Biotechnol 2004;79:809-15.

Domingues L, Lima N, Teixeira JA. Aspergillus niger beta-galactosidase production by yeast in a continuous high cell density reactor. Process Biochem 2005;40:1151-4.

Domingues L, Guimarães PM, Oliveira C. Metabolic engineering of Saccharomyces cerevisiae for lactose/whey fermentation. Bioengineered Bugs 2010;1:164-71.

Ferraz RM, Aris A, Martinez MA, Villaverde A. High-throughput, functional screening of the anti-HIV-1 humoral response by an enzymatic nanosensor. Mol Immunol 2006;43:2119-23.

Ferraz RM, Martinez MA, Cubarsi R, Villaverde A. Antiretroviral therapy-induced functional modification of IgG4 and IgM responses in HIV-1-infected individuals screened by an allosteric biosensor. J Biomol Screen 2008;13:817-21.

Gänzle MG, Haase G, Jelen P. Lactose: crystallization, hydrolysis and value-added derivatives. Int Dairy J 2008;18:685-94.

Gasteiger E, Gattiker A, Hoogland C, Ivanyi I, Appel RD, Bairoch A. ExPASy: the proteomics server for in-depth protein knowledge and analysis. Nucleic Acids Res 2003;31:3784-8.

Gosling A, Stevens GW, Barber AR, Kentish SE, Gras SL. Recent advances refining galactooligosaccharide production from lactose. Food Chem 2010;121:307-18.

Guarente L. Yeast promoters and lacZ fusions designed to study expression of cloned genes in yeast. Methods Enzymol 1983;101:181-91.

Guimarães PM, Teixeira JA, Domingues L. Fermentation of lactose to bio-ethanol by yeasts as part of integrated solutions for the valorisation of cheese whey Biotechnol Adv 2010;28:375-84.

Halbmayr E, Mathiesen G, Nguyen TH, Maischberger T, Peterbauer CK, Eijsink VGH et al. High-level expression of recombinant beta-galactosidases in Lactobacillus plantarum and Lactobacillus sakei using a sakacin P-based expression system. J Agric Food Chem 2008;56:4710-9.

Hildebrandt P, Wanarska M, Kur J. A new cold-adapted beta-D-galactosidase from the Antarctic Arthrobacter sp 32c-gene cloning, overexpression, purification and properties. BMC Microbiol 2009;9:151.

Hirata $H$, Fukazawa T, Negoro S, Okada $H$. Structure of a beta-galactosidase gene of Bacillus stearothermophilus. J Bacteriol 1986;166:722-7.

Huang SF, Liu DB, Zeng JM, Yuan Y, Xiao Q, Sun CM, et al. Cloning, expression, purification, distribution and kinetics characterization of the bacterial betagalactosidase fused to the cytoplasmic transduction peptide in vitro and in vivo. Protein Expr Purif 2009;68:167-76.

Hung MN, Lee BH. Purification and characterization of a recombinant betagalactosidase with transgalactosylation activity from Bifidobacterium infantis HL96. Appl Microbiol Biotechnol 2002;58:439-45.

Husain Q. Beta galactosidases and their potential applications: a review. Crit Rev Biotechnol 2010;30:41-62.

Iqbal S, Nguyen TH, Nguyen TT, Maischberger T, Haltrich D. Beta-galactosidase from Lactobacillus plantarum WCFS1: biochemical characterization and formation of prebiotic galacto-oligosaccharides. Carbohydr Res 2010;345:1408-16.

Ji ES, Park NH, Oh DK. Galacto-oligosaccharide production by a thermostable recombinant beta-galactosidase from Thermotoga maritima. World J Microbiol Biotechnol 2005;21:759-64.

Kang SK, Cho KK, Ahn JK, Bok JD, Kang SH, Woo JH, et al. Three forms of thermostable lactose-hydrolase from Thermus sp. IB-21: cloning, expression, and enzyme characterization. J Biotechnol 2005;116:337-46.

Kim CS, Ji ES, Oh DK. Characterization of a thermostable recombinant betagalactosidase from Thermotoga maritima. J Appl Microbiol 2004;97:1006-14.

Kim YS, Park CS, Oh DK. Lactulose production from lactose and fructose by a thermostable beta-galactosidase from Sulfolobus solfataricus. Enzyme Microb Technol 2006;39:903-8.

Kim BG, Lee KJ, Han NS, Park KH, Lee SB. Enzymatic synthesis and characterization of galactosyl trehalose trisaccharides. Food Sci Biotechnol 2007;16:127-32.

Klewicki R. Effect of selected parameters of lactose hydrolysis in the presence of betagalactosidase from various sources on the synthesis of galactosyl-polyol derivatives. Eng Life Sci 2007a;7:268-74.

Klewicki R. Formation of gal-sorbitol during lactose hydrolysis with beta-galactosidase. Food Chem 2007b;100:1196-201.

Kosseva MR, Panesar PS, Kaur G, Kennedy JF. Use of immobilised biocatalysts in the processing of cheese whey. Int J Biol Macromol 2009;45:437-47.

Kumar V, Ramakrishnan S, Teeri TT, Knowles JKC, Hartley BS. Saccharomyces cerevisiae cells secreting an Aspergillus niger beta-galactosidase grow on whey permeate. BioTechnology 1992;10:82-5. 
Lachance MA. Kluyveromyces van der Walt emend. van der Walt. In: Kurtzman CP, Fell JW, editors. The yeasts, a taxonomic study. Amsterdam: Elsevier; 1998. p. 227-47.

Leahy M, Vaughan P, Fanning L, Fanning S, Sheehan D. Purification and some characteristics of a recombinant dimeric Rhizobium melioloti beta-galactosidase expressed in Escherichia coli. Enzyme Microb Technol 2001;28:682-8.

Lee YJ, Kim CS, Oh DK. Lactulose production by beta-galactosidase in permeabilized cells of Kluyveromyces lactis. Appl Microbiol Biotechnol 2004;64:787-93.

Li L, Zhang M, Jiang Z, Tang L, Cong Q. Characterisation of a thermostable family 42 betagalactosidase from Thermotoga maritima. Food Chem 2009a;112:844-50.

Li W, Xiang X, Tang S, Hu B, Tian L, Sun Y, et al. Effective enzymatic synthesis of lactosucrose and its analogues by beta-D-galactosidase from Bacillus circulans. J Agric Food Chem 2009b;57:3927-33.

Lifran EV, Hourigan JA, Sleigh RW, Johnson RL. New wheys for lactose. Food Aust 2000;52:120-5.

Lu LL, Xiao M, Li ZY, Li YM, Wang FS. A novel transglycosylating beta-galactosidase from Enterobacter cloacae B5. Process Biochem 2009;44:232-6.

Lu L, Xu X, Gu G, Jin L, Xiao M, Wang F. Synthesis of novel galactose containing chemicals by beta-galactosidase from Enterobacter cloacae B5. Bioresour Technol 2010;101: 6868-72.

Madoz J, Kuznetzov BA, Medrano FJ, Garcia JL, Fernandez VM. Functionalization of gold surfaces for specific and reversible attachment of a fused beta-galactosidase and choline-receptor protein. J Am Chem Soc 1997;119:1043-51.

Maischberger T, Mierau I, Peterbauer CK, Hugenholtz J, Haltrich D. High-level expression of Lactobacillus beta-galactosidases in Lactococcus lactis using the food-grade, nisincontrolled expression system NICE. J Agric Food Chem 2010;58:2279-87.

Nguyen TH, Splechtna B, Yamabhai M, Haltrich D, Peterbauer C. Cloning and expression of the beta-galactosidase genes from Lactobacillus reuteri in Escherichia coli. J Biotechnol 2007;129:581-91.

Oliveira C, Teixeira JA, Lima N, Da Silva NA, Domingues L. Development of stable flocculent Saccharomyces cerevisiae strain for continuous Aspergillus niger betagalactosidase production. J Biosci Bioeng 2007;103:318-24.

Pan Q, Zhu J, Liu L, Cong Y, Hu F, Li J, et al. Functional identification of a putative betagalactosidase gene in the special lac gene cluster of Lactobacillus acidophilus. Curr Microbiol 2010;60:172-8.

Panesar PS, Panesar R, Singh RS, Kennedy JF, Kumar H. Microbial production, immobilization and applications of beta-D-galactosidase. J Chem Techno Biotechnol 2006;81:530-43.

Park AR, Oh DK. Effects of galactose and glucose on the hydrolysis reaction of a thermostable beta-galactosidase from Caldicellulosiruptor saccharolyticus. Appl Microbiol Biotechnol 2010a;85:1427-35.

Park AR, Oh DK. Galacto-oligosaccharide production using microbial beta-galactosidase: current state and perspectives. Appl Microbiol Biotechnol 2010b;85:1279-86.

Pessela BC, Vian A, Mateo C, Fernández-Lafuente R, García JL, Guisán JM, et al. Overproduction of Thermus sp. Strain T2 beta-galactosidase in Escherichia coli and preparation by using tailor-made metal chelate supports. Appl Environ Microbiol 2003;69:1967-72.

Pignatelli R, Vai M, Alberghina L, Popolo L. Expression and secretion of betagalactosidase in Saccharomyces cerevisiae using the signal sequences of GgpI, the major yeast glycosylphosphatidylinositol-containing protein. Biotechnol Appl Biochem 1998;27(Pt 2):81-8.
Placier G, Watzlawick H, Rabiller C, Mattes R. Evolved beta-galactosidases from Geobacillus stearothermophilus with improved transgalactosylation yield for galacto-oligosaccharide production. Appl Environ Microbiol 2009;75:6312-21.

Porro D, Martegani E, Ranzi BM, Alberghina L. Lactose/whey utilization and ethanol production by transformed Saccharomyces cerevisiae cells. Biotechnol Bioeng 1992;39:799-805.

Ramakrishnan S, Hartley BS. Fermentation of lactose by yeast cells secreting recombinant fungal lactase. Appl Environ Microbiol 1993;59:4230-5.

Rhimi M, Aghajari N, Jaouadi B, Juy M, Boudebbouze S, Maguin E, et al. Exploring the acidotolerance of beta-galactosidase from Lactobacillus delbrueckii subsp. bulgaricus: an attractive enzyme for lactose bioconversion. Res Microbiol 2009;160:775-84

Richmond ML, Gray JI, Stine CM. Beta-galactosidase - review of recent research related to technological application, nutritional concerns, and immobilization. J Dairy Sci 1981;64:1759-71.

Rodríguez AP, Leiro RF, Trillo MC, Cerdán ME, Siso MIG, Becerra M. Secretion and properties of a hybrid Kluyveromyces lactis - Aspergillus niger beta-galactosidase. Microb Cell Fact 2006;5:41.

Sánchez-Aparicio MT, Rosas MF, Ferraz RM, Delgui L, Veloso JJ, Blanco E, et al. Discriminating foot-and-mouth disease virus-infected and vaccinated animals by use of beta-galactosidase allosteric biosensors. Clin Vaccine Immunol 2009;16: 1228-35.

Schmidt M, Stougaard P. Identification, cloning and expression of a cold-active betagalactosidase from a novel Arctic bacterium, Alkalilactibacillus ikkense. Environ Technol 2010;31:1107-14.

Shuklaa TP, Wierzbickib LE. Beta-galactosidase technology: a solution to the lactose problem. Crit Rev Food Sci Nutr 1975;5:325-56.

Siso MIG. The biotechnological utilization of cheese whey: a review. Bioresour Technol 1996;57:1-11.

Song C, Chi Z, Li J, Wang X. Beta-galactosidase production by the psychrotolerant yeast Guehomyces pullulans 17-1 isolated from sea sediment in Antarctica and lactose hydrolysis. Bioprocess Biosyst Eng 2010;33:1025-31.

Terrell SL, Bernard A, Bailey RB. Ethanol from whey - continuous fermentation with a catabolite repression-resistant Saccharomyces cerevisiae mutant. Appl Environ Microbiol 1984;48:577-80

Vanoni M, Porro D, Martegani E, Alberghina L. Secretion of Escherichia coli betagalactosidase in Saccharomyces cerevisiae using the signal sequence from the glucoamylase-encoding STA2 gene. Biochem Biophys Res Commun 1989;164:1331-8.

Venturini M, Morrione A, Pisarra P, Martegani E, Vanoni M. In Saccharomyces cerevisiae a short amino acid sequence facilitates excretion in the growth medium of periplasmic proteins. Mol Microbiol 1997;23:997-1007.

Xia Y, Zhao J, Chen H, Liu X, Wang Y, Tian F, et al. Extracellular secretion in Bacillus subtilis of a cytoplasmic thermostable beta-galactosidase from Geobacillus stearothermophilus. J Dairy Sci 2010;93:2838-45.

Yang ST, Silva EM. Novel products and new technologies for use of a familiar carbohydrate, milk lactose. J Dairy Sci 1995;78:2541-62.

Yuan TZ, Yang PL, Wang YR, Meng K, Luo HY, Zhang W, et al. Heterologous expression of a gene encoding a thermostable beta-galactosidase from Alicyclobacillus acidocaldarius. Biotechnol Lett 2008;30:343-8.

Zadow JG. Lactose - properties and uses. J Dairy Sci 1984;67:2654-79. 